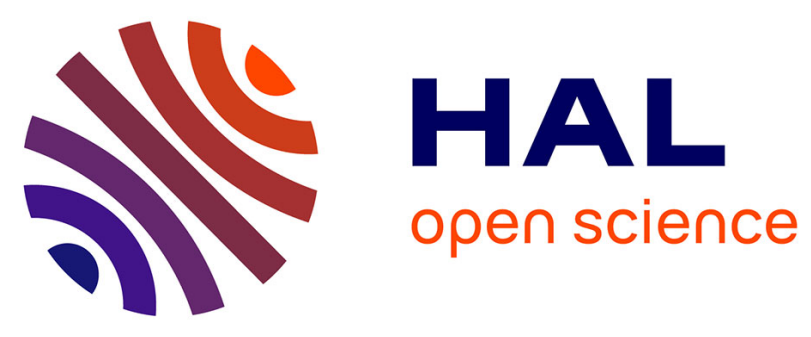

\title{
Saccharothrix sp. PAL54, a new chloramphenicol-producing strain isolated from a Saharan soil
}

Adel Aouiche, Nasserdine Sabaou, Atika Meklat, Abdelghani Zitouni, Christian Bijani, Florence Mathieu, Ahmed Lebrihi

\section{To cite this version:}

Adel Aouiche, Nasserdine Sabaou, Atika Meklat, Abdelghani Zitouni, Christian Bijani, et al.. Saccharothrix sp. PAL54, a new chloramphenicol-producing strain isolated from a Saharan soil. World Journal of Microbiology and Biotechnology, 2012, vol. 28, pp. 943-951. 10.1007/s11274-011-0892-2 . hal-00878422

\section{HAL Id: hal-00878422 \\ https://hal.science/hal-00878422}

Submitted on 30 Oct 2013

HAL is a multi-disciplinary open access archive for the deposit and dissemination of scientific research documents, whether they are published or not. The documents may come from teaching and research institutions in France or abroad, or from public or private research centers.
L'archive ouverte pluridisciplinaire HAL, est destinée au dépôt et à la diffusion de documents scientifiques de niveau recherche, publiés ou non, émanant des établissements d'enseignement et de recherche français ou étrangers, des laboratoires publics ou privés. 


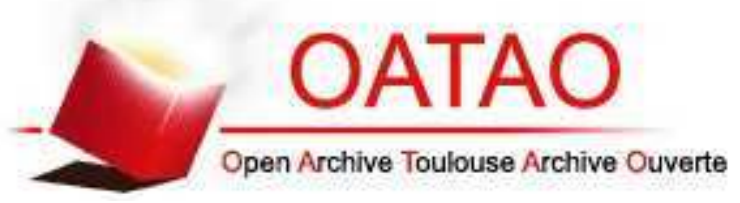

\section{Open Archive TOULOUSE Archive Ouverte (OATAO)}

OATAO is an open access repository that collects the work of Toulouse researchers and makes it freely available over the web where possible.

This is an author-deposited version published in : http://oatao.univ-toulouse.fr/ Eprints ID : 9974

To link to this article : DOI:10.1007/s11274-011-0892-2

URL : http://dx.doi.org/10.1007/s11274-011-0892-2

To cite this version : Aouiche, Adel and Sabaou, Nasserdine and Meklat, Atika and Zitouni, Abdelghani and Bijani, Christian and Mathieu, Florence and Lebrihi, Ahmed. Saccharothrix sp. PAL54, a new chloramphenicol-producing strain isolated from a Saharan soil. (2012) World Journal of Microbiology and Biotechnology, vol. 28 (n 3). pp. 943-951. ISSN 0959-3993

Any correspondance concerning this service should be sent to the repository administrator: staff-oatao@ listes-diff.inp-toulouse.fr 


\title{
Saccharothrix sp. PAL54, a new chloramphenicol-producing strain isolated from a Saharan soil
}

\author{
Adel Aouiche - Nasserdine Sabaou - Atika Meklat • \\ Abdelghani Zitouni - Christian Bijani • \\ Florence Mathieu • Ahmed Lebrihi
}

\begin{abstract}
An actinomycete strain designated PAL54, producing an antibacterial substance, was isolated from a Saharan soil in Ghardaïa, Algeria. Morphological and chemical studies indicated that this strain belonged to the genus Saccharothrix. Analysis of the 16S rDNA sequence showed a similarity level ranging between 96.9 and $99.2 \%$ within Saccharothrix species, with $S$. longispora DSM $43749^{\mathrm{T}}$, the most closely related. DNA-DNA hybridization confirmed that strain PAL54 belonged to Saccharothrix longispora. It showed very strong activity against pathogenic Gram-positive and Gram-negative bacteria responsible for nosocomial infections and resistant to multiple antibiotics. Strain PAL54 secreted the antibiotic optimally during mid-stationary and decline phases of growth. One antibacterial compound was isolated from the culture broth and purified by HPLC. The active compound was elucidated
\end{abstract}

A. Aouiche $\cdot$ N. Sabaou $(\bowtie) \cdot$ A. Meklat $\cdot$ A. Zitouni Laboratoire de Recherche sur les Produits Bioactifs et la Valorisation de la Biomasse, Ecole Normale Supérieure de Kouba, B.P. 92, 16050 Vieux-Kouba, Alger, Algeria e-mail: sabaou@yahoo.fr

\section{Bijani}

Laboratoire de Chimie de Coordination (LCC), CNRS,

Toulouse, France

\section{Bijani}

Université de Toulouse, UPS, INPT, LCC, 205 Route de

Narbonne, 31077 Toulouse, France

F. Mathieu · A. Lebrihi

Laboratoire de Génie Chimique UMR 5503 (CNRS/INPT/UPS),

ENSAT/INP de Toulouse, Université de Toulouse, 1 avenue de

l'Agrobiopôle, Castanet-Tolosan Cedex, France

\section{A. Lebrihi}

Université Moulay Ismail, Marjane 2, BP 298, Meknes, Maroc by uv-visible and NMR spectroscopy and by mass spectrometry. The results showed that this compound was a $\mathrm{D}(-)$-threo chloramphenicol. This is the first report of chloramphenicol production by a Saccharothrix species.

Keywords Actinomycete - Taxonomy - Saccharothrix . Antibacterial activities - Chloramphenicol

\section{Introduction}

Because of the increasing resistance of pathogenic microorganisms to antibiotics, research has intensified to discover new bioactive molecules. Several published studies have reported the emergence of new bacterial strains resistant to many antibiotics including some clinically used cephalosporins of 3rd and 4th generation (Katsumi et al. 2005; Sekhsokh et al. 2008). Studies on the emergence of multidrug-resistant bacteria responsible for nosocomial infections have also been reported in Algeria (Touati et al. 2006; Aggoune-Khinache et al. 2008; Messai et al. 2008). Recently, a new gene called New Delhi metallo-beta-lactamase (NDM-1) was discovered in several enterobacteria. It allows them to synthesize an enzyme inactivating most beta-lactam antibiotics used in therapy and thus constitutes a real health hazard (Kumarasamy et al. 2010).

Actinomycetes are particularly interesting for their high capacity to produce secondary metabolites with diverse chemical structures (Valan Arasu et al. 2008). It has been estimated that approximately two-thirds of natural antibiotics have been isolated from actinomycetes, and about $75 \%$ are produced by members of the genus Streptomyces (Solanki et al. 2008). However, in recent years, the rate of discovery of new antibiotics in the genus Streptomyces has been declining and isolation of other actinomycete genera 
appears to be necessary to find novel strains producing commercially valuable antibiotics. Many interesting antibiotics are also produced by other genera of actinomycetes such as Micromonospora, Nocardia, Nocardiopsis, Saccharothrix, Actinomadura, Actinoplanes, Amycolatopsis, Saccharopolyspora, and Streptosporangium (Genilloud et al. 2011).

Intensive programs looking for antibiotics are running worldwide. The approaches considered in these research programs include the isolation of new antibiotics from actinomycetes other than the genus Streptomyces and the exploration of new and uncommon ecosystems. Algerian Saharan soils are exposed to an arid climate and represent particular ecosystems. In our laboratory, during a screening program of the search for new antibiotics from nonStreptomyces genera, selective isolation methods were used to isolate a number of active actinomycete strains from Algerian Saharan soils (Sabaou et al. 1998), and novel antibiotic molecules were obtained (Lamari et al. 2002; Zitouni et al. 2004b; Boudjella et al. 2010; Merrouche et al. 2010).

As part of this program, an actinomycete strain PAL54 was isolated and identified as belonging to the genus Saccharothrix. It showed interesting activity against pathogenic Gram-positive and Gram-negative bacteria responsible for nosocomial infections and resistant to many antibiotics.

This paper reports the taxonomy of the organism, and the production, purification and structure elucidation of the active molecule.

\section{Materials and methods}

Strain isolation

The actinomycete strain designated PAL54 was isolated from a Saharan soil collected in Ghardaïa (latitude, $32^{\circ} 24^{\prime} \mathrm{N}$; longitude, $03^{\circ} 48^{\prime} \mathrm{E}$; altitude, $468 \mathrm{~m}$ ). The dry soil sample was suspended in sterile distilled water and diluted. Aliquots $(0.2 \mathrm{~mL})$ of each dilution were spread onto chitinvitamins agar (Hayakawa and Nonomura 1987). The medium was supplemented with polymyxin $\left(25 \mathrm{mg} \mathrm{L}^{-1}\right)$ and cycloheximide $\left(80 \mathrm{mg} \mathrm{L}^{-1}\right)$ to inhibit the growth of bacteria and fungi respectively. The plates were incubated at $30^{\circ} \mathrm{C}$ for 2 weeks.

\section{Morphological and chemical characterization}

The genus of the collected isolate was identified by morphological characteristics and chemical analysis of cellular components. The morphological and cultural features were observed by naked-eye examination of 14 day-old cultures grown on various International Streptomyces Project (ISP) media: yeast extract-malt extract agar (ISP-2), oatmeal agar (ISP-3), inorganic salts-starch agar (ISP-4), glycerolasparagine agar (ISP-5) (Shirling and Gottlieb 1966) and on Bennett medium. The micromorphology and sporulation were observed by light microscopy. Colors of aerial and substrate mycelia were determined with the ISCC-NBS color charts (Kelly and Judd 1976).

For chemotaxonomic analyses, biomass was obtained from a culture grown in shake ISP- 2 medium (Shirling and Gottlieb 1966) and incubated at $30^{\circ} \mathrm{C}$ for 4 days. Diaminopimelic acid isomers, whole-cell sugar pattern and phospholipids were analyzed according to the methods of Becker et al. (1964), Lechevalier and Lechevalier (1970) and Minnikin et al. (1977) respectively.

Physiological characterization

Production of melanoid pigments was tested on peptoneyeast extract-iron agar (ISP-6) and tyrosine agar (ISP-7) media (Shirling and Gottlieb 1966). The assimilation of carbohydrate as sole carbon source was determined on ISP-9 medium (Shirling and Gottlieb 1966). The decomposition of hypoxanthine and xanthine and assimilation of amino acid as sole nitrogen source were evaluated as described by Locci (1989). Degradation of starch and production of nitrate reductase were determined as previously described (Marchal et al. 1987). Sensitivities to sodium chloride (4 and 7\% w/v) and growth at $45^{\circ} \mathrm{C}$ were evaluated on Bennett medium.

DNA extraction, 16S rDNA sequencing, phylogenetic analysis and DNA-DNA hybridization

DNA was extracted according to the method of Liu et al. (2000). The strain PAL54 was grown at $30^{\circ} \mathrm{C}$ for 4 days with agitation $(250 \mathrm{rpm})$ in a $500 \mathrm{~mL}$ flask containing $100 \mathrm{~mL}$ of ISP- 2 medium. The $16 \mathrm{~S}$ rDNA was amplified by PCR using an Invitrogen kit and two primers: 27f (5'-AGAGTTT GATCCTGGCTCAG-3') and 1492r (5'-GGTTACCTTGTT ACGACTT- $\left.3^{\prime}\right)$. The final $50-\mu \mathrm{L}$ volume of reaction mixture contained $1 \times$ PCR buffer (Tris-HCl $10 \mathrm{mM}$; KCl $50 \mathrm{mM}$; $\mathrm{pH} 9.0$ at $25^{\circ} \mathrm{C}$ ), $1.5 \mathrm{mM}$ of $\mathrm{MgCl}_{2}, 200 \mathrm{mM}$ of each dNTP, $1 \mathrm{mM}$ of each primer, $1.25 \mathrm{U}$ of Taq DNA polymerase and $1 \mu \mathrm{L}$ (500 ng) of the purified DNA. PCR amplification of the 16 rDNA was carried out on a Stratagene RoboCycler Gradient 96. The conditions for thermal cycling were as follows: denaturation of the target DNA at $98^{\circ} \mathrm{C}$ for $3 \mathrm{~min}$ followed by 30 cycles of $94^{\circ} \mathrm{C}$ for $1 \mathrm{~min}$, primer annealing at $52^{\circ} \mathrm{C}$ for $1 \mathrm{~min}$ and primer extension at $72^{\circ} \mathrm{C}$ for $2 \mathrm{~min}$. At the end of the cycling, the reaction mixture was held at $72^{\circ} \mathrm{C}$ for $10 \mathrm{~min}$ and then cooled to $4^{\circ} \mathrm{C}$. The PCR product was detected by agarose gel electrophoresis and was visualized by ultraviolet (uv) fluorescence after ethidium bromide staining. 
The sequencing reaction was performed by the MilleGen Company (Toulouse, France). The same primers as before and an automated sequencer were used for this purpose. The sequence obtained was compared for similarity level with available sequences of the reference species of bacteria contained in the GenBank database, using the "NCBI Blast'" available at the ncbi-nlm-nih.gov website. Phylogenetic and molecular evolutionary analyses were carried out using software included in the MEGA version 3.0 (Kumar et al. 2004) package. The 16S rDNA sequence of strain PAL54 was aligned using the CLUSTAL W program (Thompson et al. 1994) against corresponding nucleotide sequences of representatives of the genus Saccharothrix recovered from GenBank. Evolutionary distance matrices were generated as described by Jukes and Cantor (1969) and a phylogenetic tree was constructed using the neighbor-joining method of Saitou and Nei (1987). The topology of the tree was evaluated by bootstrap analysis (Felsenstein 1985) using 1,000 resamplings.

DNA was extracted from cells using Marmur's method (1961) and purified by chromatography on hydroxyapatite as described by Cashion et al. (1977). DNA-DNA relatedness between strains was determined as described previously (Zitouni et al. 2004a) in $5 \times$ SSC $(1 \times$ SSC is $0.15 \mathrm{M}$ sodium chloride and $0.015 \mathrm{M}$ sodium citrate) and $20 \%$ dimethyl sulfoxide at $66^{\circ} \mathrm{C}$ (melting point $-23^{\circ} \mathrm{C}$ ) by the method of De Ley et al. (1970), using a Perkin Elmer Lambda 35UV/VIS spectrophotometer fitted with the Peltier temperature controller, PTP-1. The experiments were performed in duplicate.
Antimicrobial activity

Antimicrobial activity was evaluated on ISP-2 and Bennett media by the streak method against various microorganisms. The experiment was done firstly by streaking a straight line of the PAL54 inoculum across the surface of medium on $90-\mathrm{mm}$-diameter plates and incubating at $30^{\circ} \mathrm{C}$ for 10 days. After the growth of the isolate PAL54, target microorganisms were seeded in streaks crossing the actinomycete culture. The antimicrobial activity was appreciated by measuring the length of inhibition between target microorganisms and actinomycete colony margins.

The target microorganisms, isolated from sick patients in hospitals of Algeria, were mostly multiresistant to antibiotics (Table 1). They included Gram-positive (Bacillus subtilis ATCC 6633 and Staphylococcus aureus S1) and Gram-negative (Acinetobacter baumanii E16, Enterobacter cloacae E10 and E13, Escherichia coli E52 and E195, Klebsiella pneumoniae E40 and K44, Salmonella enterica E32 and Pseudomonas aeruginosa IPA1) bacteria, yeasts (Saccharomyces cerevisiae ATCC 4226 and Candida albicans IPA200) and filamentous fungi (Aspergillus carbonarius M333 and Fusarium culmorum FC1). The measurements of distance of inhibition represent the average of two experiments.

Time course of growth and antibiotic production

Fermentations were conducted in Bennett broth. A seed culture was prepared with the same medium and used to inoculate a $500 \mathrm{~mL}$ Erlenmeyer flask containing $100 \mathrm{~mL}$

Table 1 Resistance patterns of target bacteria

\begin{tabular}{|c|c|c|}
\hline Microorganisms & Resistance to & Sensitivity to \\
\hline Bacillus subtilis ATCC 6633 & $\mathrm{NEO}$ & $\begin{array}{c}\text { C, CAR, CHL, ERY, GEN, } \\
\text { K, RIF, SPI, SSS, VAN }\end{array}$ \\
\hline Staphylococcus aureus $\mathrm{S} 1$ & CAR, GEN, K, NEO, OLE, SPI, VAN & $\mathrm{C}, \mathrm{CHL}$ \\
\hline Acinetobacter baumanii E16 & AMC, ATM, CFP, CTX, FEP, GEN, PIP, TOB & AMC, C, CXC, FOX, TCC, TIC, TZP \\
\hline Enterobacter cloacae E10 & AMC, ATM, CAZ, CFP, CTX, FEP, GEN, PIP, TCC, TIC, TOB & $\mathrm{C}, \mathrm{CXC}, \mathrm{FOX}, \mathrm{TZP}$ \\
\hline Enterobacter cloacae E13 & AMC, ATM, CFP, CTX, FEP, FOX, GEN, PIP, TCC, TIC, TOB, TZP & $\mathrm{C}, \mathrm{CXC}$ \\
\hline Escherichia coli $\mathrm{E} 52$ & AMX, ATM, CAZ, CFP, CTX, FEP, GEN, PIP, TIC, TOB & $\mathrm{AMC}, \mathrm{C}, \mathrm{CXC}, \mathrm{FOX}, \mathrm{TCC}, \mathrm{TZP}$ \\
\hline Escherichia coli $\mathrm{E} 195$ & AMC, AMX, CAZ, CF, CTX, CXM, FOX, TCC, TIC & $\mathrm{C}, \mathrm{CXC}$ \\
\hline Klebsiella pneumoniae E40 & AMX, CAZ, CFP, CTX, FEP, GEN, PIP, TIC, TOB & AMC, ATM, C, CXC, TCC \\
\hline Klebsiella pneumoniae $\mathrm{K} 44$ & AMX, ATM, CF, CTX, CXM, GEN, K, MZ, SSS, TIC, TOB & $\mathrm{AMC}, \mathrm{C}, \mathrm{CXC}, \mathrm{TCC}$ \\
\hline Salmonella enterica $\mathrm{E} 32$ & ATM, CAZ, CFP, CTX, FEP, GEN, PIP, TIC, TOB & $\mathrm{C}, \mathrm{CXC}, \mathrm{FOX}, \mathrm{TCC}, \mathrm{TZP}$ \\
\hline $\begin{array}{l}\text { Pseudomonas aeruginosa } \\
\text { IPA1 }\end{array}$ & CAR, ERY, GEN, NEO, SPI, SSS & $\mathrm{C}, \mathrm{CHL}, \mathrm{K}, \mathrm{RIF}$ \\
\hline
\end{tabular}

$A M C$ amoxicillin + clavulanic acid, $A M X$ amoxicillin, $A T M$ aztreonam, $C$ chloramphenicol, $C A R$ carbenicillin, $C A Z$ ceftazidim, $C F$ cefalotin, $C F P$ cefpirom, $C H L$ chlortetracycline, $C T X$ cefotaxime, $C X C$ cefotaxime + clavulanic acid, $C X M$ cefuroxime, $E R Y$ erythromycin, $F E P$ cefepime, $F O X$ cefoxitin, $G E N$ gentamicin, $K$ kanamycin, $M Z$ mezlocillin, $N E O$ neomycin, $O L E$ oleandomycin, $P I P$ piperacillin, $R I F$ rifampicin, $S P I$ spiramycin, SSS sulfonamide, TCC ticarcillin + clavulanic acid, TIC ticarcillin, TOB tobramycin, TZP piperacillin + tazobactam, VAN vancomycin 
of Bennett. The cultures were incubated on a rotary shaker $(250 \mathrm{rpm})$ at $30^{\circ} \mathrm{C}$ for 14 days. The antibacterial activities were assayed daily against Bacillus subtilis ATCC 6633 and Klebsiella pneumoniae E40 by the agar diffusion method (well technique). The growth (dry weight of mycelium) and the $\mathrm{pH}$ were also measured.

The amounts of the antibiotic produced were estimated from the 4th to 10th day by correlation between the diameters of inhibition obtained with the active compound present in the culture filtrate and those obtained with the purified active compound (as described in the following paragraph). In both cases the agar diffusion method (well technique) was used with Bacillus subtilis ATCC 6633 (which is the most sensitive) as target microorganism.

\section{Isolation and purification of antibiotic}

The extraction of active compound took place on the day of optimal production rate. The Bennett culture broth ( $250 \mathrm{~mL}$ ) was centrifuged to remove the biomass. The cellfree supernatant was extracted with an equal volume of dichloromethane. The organic extract was concentrated to dryness.

The resulting dry extract was recuperated in $0.5 \mathrm{~mL}$ of methanol and bioassayed against Bacillus subtilis ATCC 6633 and Klebsiella pneumoniae E40 by the paper disk diffusion method. Preparative chromatography with silica gel plates (Merck Art. 5735, Kiesselgel 60HF 254-366; $20 \times 20 \mathrm{~cm}$ ) was employed for the partial purification of antimicrobial products. A dry crude extract, dissolved in methanol, was spotted and developed in the solvent system (ethyl acetate-methanol, 100:15 v/v). The developed TLC plates were air dried overnight to remove all traces of solvents. The separated compounds were visualized under uv at $254 \mathrm{~nm}$ (absorbance) and at $365 \mathrm{~nm}$ (fluorescence), and the active spot was detected by bioautography (Betina 1973). The TLC plates were deposited in a plastic bioassay dish $(23 \mathrm{~cm} \times 23 \mathrm{~cm} \times 2.2 \mathrm{~cm}$, Fisher Scientific Labosi) and overlayed with $50 \mathrm{~mL}$ (per plate) of ISP-2 medium (containing $7 \mathrm{~g} \mathrm{~L}^{-1}$ agar) seeded with Bacillus subtilis ATCC 6633 or Klebsiella pneumoniae E40 as target microorganisms, and incubated at $30^{\circ} \mathrm{C}$ for $24 \mathrm{~h}$. A clear area due to the inhibition of the growth of target microorganisms indicated the location of the antibiotic compound. The retention factor (Rf) of the active spot was measured.

The final purification of the antibiotic was performed by Waters reverse phase HPLC using an XBridge C18 $(5 \mu \mathrm{m})$ column $(200 \times 10 \mathrm{~mm}$, Waters $)$ with a continuous linear gradient solvent system from 20 to $100 \%$ methanol in water, a flow rate of $2 \mathrm{~mL} \mathrm{~min}^{-1}$ and uv detection at 220 and $254 \mathrm{~nm}$. The final purification was achieved after the second re-injection in the HPLC system.
Spectroscopic analysis of antibiotic

The uv absorption spectrum of the active molecule in methanol was determined with a Shimadzu uv 1,605 spectrophotometer. The mass spectrum was recorded on an ion-trap mass spectrometer (Finnigan MAT, San Jose, CA), equipped with a nanospray ion electro-spray ionization (ESI) source (negative ion mode).

An NMR sample was prepared by dissolving $2 \mathrm{mg}$ of antibiotic compound in $600 \mu \mathrm{L}$ of $\mathrm{CD}_{3} \mathrm{OD}$. All spectra were recorded on a Bruker Avance 500 spectrometer equipped with a $5 \mathrm{~mm}$ triple resonance inverse $\mathrm{Z}$-gradient probe (TBI $1 \mathrm{H}, 31 \mathrm{P}, \mathrm{BB})$. All chemical shifts for ${ }^{1} \mathrm{H}$ and ${ }^{13} \mathrm{C}$ were relative to TMS using ${ }^{1} \mathrm{H}$ (residual) or ${ }^{13} \mathrm{C}$ chemical shifts of the solvent as a secondary standard. The temperature was set at $298 \mathrm{~K}$. Gradient-enhanced ${ }^{1} \mathrm{H}$ COSY45 was performed including 36 scans per increment. ${ }^{1} \mathrm{H}-{ }^{13} \mathrm{C}$ correlation spectra using a gradient-enhanced HSQC sequence (delay optimized for $1 \mathrm{JCH}$ of $145 \mathrm{~Hz}$ ) were obtained with 120 scans per increment. A gradientenhanced HMBC experiment was performed allowing $62.5 \mathrm{~ms}$ for long-range coupling evolution (240 scans were accumulated). Typically, 2,048 t2 data points were collected for $256 \mathrm{t} 1$ increments.

\section{Results and discussion}

\section{Taxonomy}

The strain PAL54 formed a well-developed aerial mycelium which fragmented anarchically into long, straight, flexuous, open loops and hooks. The spores were rodshaped and $1.5-2.5 \times 0.6-0.8 \mu \mathrm{m}$ in size. The sporulation was better on ISP-2, ISP-5 and Bennett media. The substrate mycelium was branched and partially fragmented into rod-like elements. Endospores, sclerotic granules, synnemata and flagellated spores were not observed. The strain showed good growth on ISP-2, ISP-3, ISP-4 and Bennett media and moderate growth on ISP-5 medium. The aerial and substrate mycelia were white and yellowish brown respectively. No soluble pigment was produced on any of the media used.

The chemotaxonomic study of strain PAL54 showed the presence of DL-diaminopimelic acid isomer and the absence of glycin in the cell wall. The whole-cell hydrolysates contained rhamnose and galactose (in addition to glucose and ribose) as characteristic sugars, typical of cell wall type IIIE (Kroppenstedt and Evtushenko 2006). The diagnostic phospholipid detected was phosphatidylethanolamine, corresponding to phospholipid type PII (Lechevalier et al. 1977). Based on its morphological and chemical characteristics, strain PAL54 was classified in the 
genus Saccharothrix (Labeda et al. 1984). This genus is reported to contain 11 species and two sub-species (Kim et al. 2011).

The 16S rDNA sequence (1,305 nucleotides) of strain PAL54 has been deposited in the GenBank data library and has been assigned the accession number JN225874.

This sequence was aligned with those of Saccharothrix reference species available in the GenBank database, which confirmed the identification of the strain at the genus level (similarity level between 96.9 and 99.2\%). Its position in the $16 \mathrm{~S}$ rDNA Saccharothrix tree is shown in Fig. 1. The similarity level was $99.2 \%$ with Saccharothrix longispora NRRL B-116116 ${ }^{\mathrm{T}}$ (Grund and Kroppenstedt 1989), the most closely related species. The physiological properties of strain PAL54 and those of the type strain of $S$. longispora are summarized in Table 2. Two physiological differences are notable and involve melibiose and hypoxanthine degradation. Moreover, strain PAL54 has a white aerial mycelium, while the $S$. longispora aerial mycelium is blue. The level of DNA-DNA relatedness between strain PAL54 and Saccharothrix longispora DSM $43749^{\mathrm{T}}$ (=RRL B-116116 ${ }^{\mathrm{T}}$ ) was $76.2 \%$ (based on the mean of duplicate determinations, 74.9 and $77.5 \%$ ), which is above the $70 \%$ relatedness guideline proposed by Wayne et al. (1987) for delineation of separate species.

Based on the genotypic results, it was concluded that strain PAL54 belonged to the species Saccharothrix longispora. However, this strain could be distinguished from S. longispora DSM $43749^{\mathrm{T}}$ by some phenotypic properties such as the color of aerial mycelium and the degradation of melibiose and hypoxanthine.
Antimicrobial activity

The antimicrobial activity of the strain PAL54 against target microorganisms is shown in Table 3. The strain showed a strong activity against Gram-negative and Grampositive bacteria such Bacillus subtilis ATCC 6633, Acinetobater baumanii E16, Staphylococcus aureus S1, Klebsiella pneumoniae E40 and K44, Escherichia coli E52 and E195 and Salmonella enterica E32, but no activity against yeasts and filamentous fungi. Bennett medium was generally better than ISP-2 medium.

The activity of Saccharothrix species against Grampositive bacteria has been widely published (Horvath et al. 1979; Takeuchi et al. 1992; Sabaou et al. 1998) but the activity against Gram-negative bacteria and fungi has been reported only rarely (Zitouni et al. 2005). Antitumoral activity has also been noted in several cases in strains of Saccharothrix (Vertesy et al. 2001; Murakami et al. 2009). No antibiotic activity is reported in the literature for Saccharothrix longispora, the species most closely related to strain PAL54.

Time course of growth and antibiotic production

During the time course of fermentation in Bennett broth, antibiotic production, dry cell weight and $\mathrm{pH}$ parameters were monitored as shown in Fig. 2. The antibacterial activity of strain PAL54 started at the mid-stationary phase of growth (4 days for Bacillus subtilis ATCC 6663 and 5 days for Klebsiella pneumoniae E40) and reached a maximum after 9 days, during the decline phase. This confirmed that the activities were due to secondary

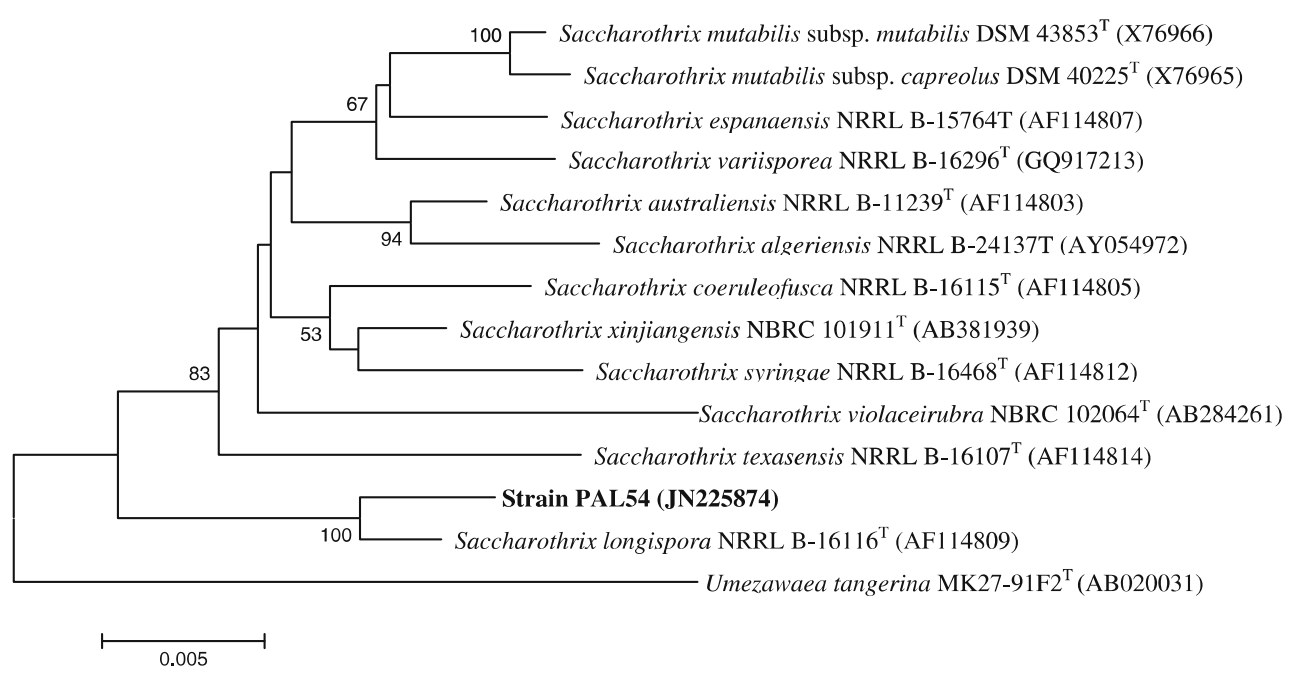

Fig. 1 Neighbor-joining tree based on 16S rDNA sequences showing the relations between strain PAL54 and type species of the genus Saccharothrix. The numbers at the nodes indicate the levels of bootstrap support based on neighbor-joining analyses of 1,000 resampled data sets. Bar, 0.005 nt substitution per nt position. Umezawaea tangerina $\mathrm{MK} 27-91 \mathrm{~F} 2^{\mathrm{T}}$ has been used as outgroup 
Table 2 Physiological properties of the strain PAL54 in comparison with those of Saccharothrix longispora

\begin{tabular}{|c|c|c|}
\hline \multirow[t]{2}{*}{ Tests } & \multicolumn{2}{|l|}{ Strains } \\
\hline & PAL54 & $\begin{array}{l}\text { S. longispora } \\
\text { NRRL B-116116 }\end{array}$ \\
\hline \multicolumn{3}{|c|}{ Carbon source utilization: } \\
\hline Arabinose & + & + \\
\hline Fructose & + & + \\
\hline Galactose & + & + \\
\hline Inositol & - & - \\
\hline Mannitol & - & - \\
\hline Melibiose & + & - \\
\hline Raffinose & - & - \\
\hline Rhamnose & + & + \\
\hline Salicine & + & + \\
\hline Sucrose & + & + \\
\hline Xylose & + & + \\
\hline \multicolumn{3}{|c|}{ Nitrogen source utilization: } \\
\hline Alanine & \pm & \pm \\
\hline Proline & + & + \\
\hline Serine & + & + \\
\hline \multicolumn{3}{|l|}{ Hydrolysis of: } \\
\hline Starch & + & + \\
\hline Hypoxanthine & + & - \\
\hline Xanthine & - & - \\
\hline Nitrate reduction & + & + \\
\hline \multicolumn{3}{|c|}{ Growth in the presence of $\mathrm{NaCl}$ : } \\
\hline $4 \% \mathrm{w} / \mathrm{v}$ & + & + \\
\hline $7 \% \mathrm{w} / \mathrm{v}$ & - & - \\
\hline Growth at $45^{\circ} \mathrm{C}$ & - & - \\
\hline
\end{tabular}

Tests: + positive; - negative; \pm doubtful

* Data from Grund and Kroppenstedt (1989) and Labeda (2002)

metabolites. The $\mathrm{pH}$ kinetics showed slight variation (between 7.0 and 8.1) during the incubation.

The amounts of the active compound obtained during the 4th, 5th, 6th, 7th, 8th, 9th and 10th days were estimated to be $3.4,4.2,15,26,30,31$ and $31 \mathrm{mg} \mathrm{L}^{-1}$, respectively.

Isolation and purification of antibiotic

On silica gel thin-layer chromatogram, the dichloromethane extract migrated and gave one bioautographic compound, which was active against Bacillus subtilis ATCC 6633 and Klebsiella pneumoniae E40. The compound, named $54 \mathrm{~A}(\mathrm{Rf}=0.74$ in ethyl-acetate-methanol, 100-15 $\mathrm{v} / \mathrm{v}$ ), showed a strong antibacterial activity and a strong absorbance under uv at $254 \mathrm{~nm}$. It was selected and purified by HPLC. The active fraction was eluted with $80 \%$ of methanol in water at a retention time of $22.80 \mathrm{~min}$. This compound was recovered and re-injected until complete
Table 3 Antimicrobial activity of strain PAL54

\begin{tabular}{lll}
\hline Target microorganisms & \multicolumn{2}{l}{$\begin{array}{l}\text { Activity of strain } \\
\text { PAL54 (in mm) }\end{array}$} \\
\cline { 2 - 3 } & $\begin{array}{l}\text { ISP-2 } \\
\text { medium }\end{array}$ & $\begin{array}{l}\text { Bennett } \\
\text { medium }\end{array}$ \\
Bacillus subtilis ATCC 6633 & 40 & 39 \\
Staphylococcus aureus S1 & 37 & 47 \\
Acinetobacter baumanii E16 & 50 & 38 \\
Enterobacter cloacae E10 & 28 & 37 \\
Enterobacter cloacae E13 & 12 & 17 \\
Escherichia coli E52 & 33 & 45 \\
Escherichia coli E195 & 46 & 50 \\
Klebsiella pneumoniae E40 & 27 & 35 \\
Klebsiella pneumoniae K44 & 28 & 34 \\
Salmonella enterica E32 & 21 & 40 \\
Pseudomonas aeruginosa IPA1 & 22 & 10 \\
Saccharomyces cerevisiae ATCC 4226 & 0 & 0 \\
Candida albicans IPA200 & 0 & 0 \\
Aspergillus carbonarius M333 & 0 & 0 \\
Fusarium culmorum FC1 & 0 & 0 \\
\hline
\end{tabular}
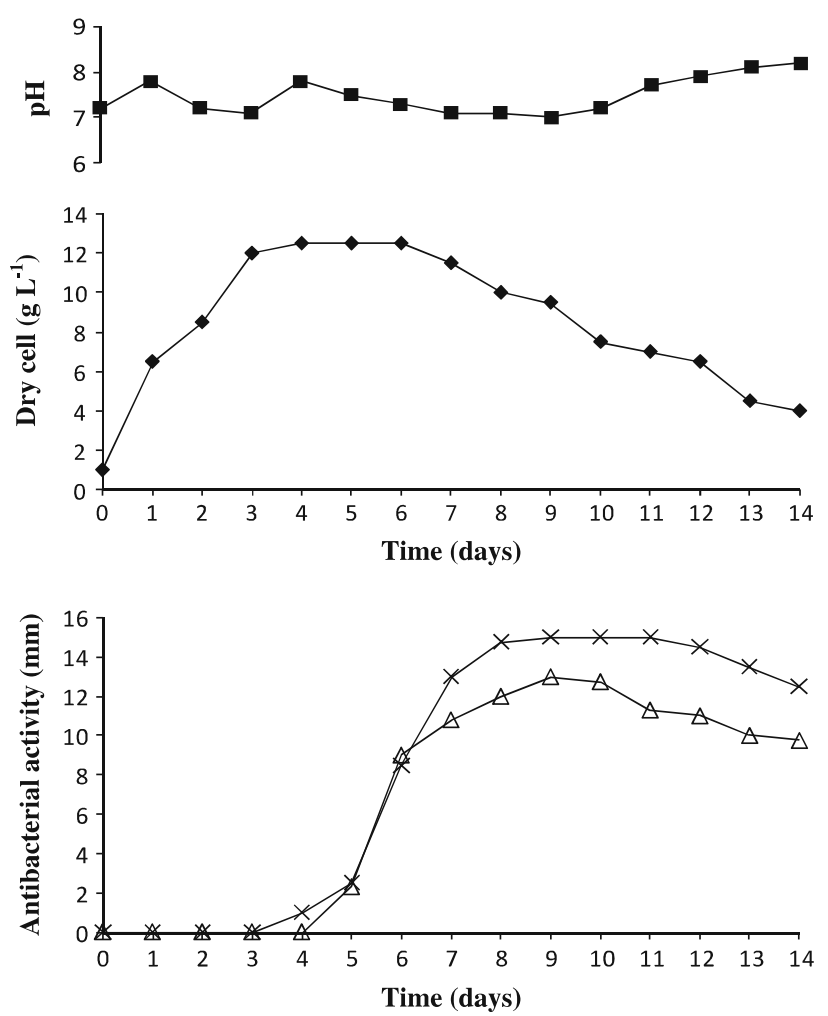

Fig. 2 Time course of $\mathrm{pH}$, growth and antibacterial activity in Bennett medium against Bacillus subtilis ATCC 6633 (cross) and Klebsiella pneumoniae $\mathrm{E} 40$ (open triangle). Measurements of activity against bacteria represent the diameters of inhibition without including the diameter of wells $(10 \mathrm{~mm})$. All experiments were repeated twice 
Fig. 3 HPLC purification process for the antibiotic secreted by the strain PAL54. a First HPLC injection of the compound $54 \mathrm{~A}(\mathrm{Rf}=0.74$ in ethyl-acetate-methanol, 100-15 $\mathrm{v} / \mathrm{v})$ resulting from the TLC silica gel. b Final purification of the compound 54A after reinjection. Column, XBridge C18 (Waters); continuous linear gradient system, $20-100 \%$ methanol in water; flow rate, $2 \mathrm{~mL} \mathrm{~min}{ }^{-1}$; detection, $220 \mathrm{~nm}$
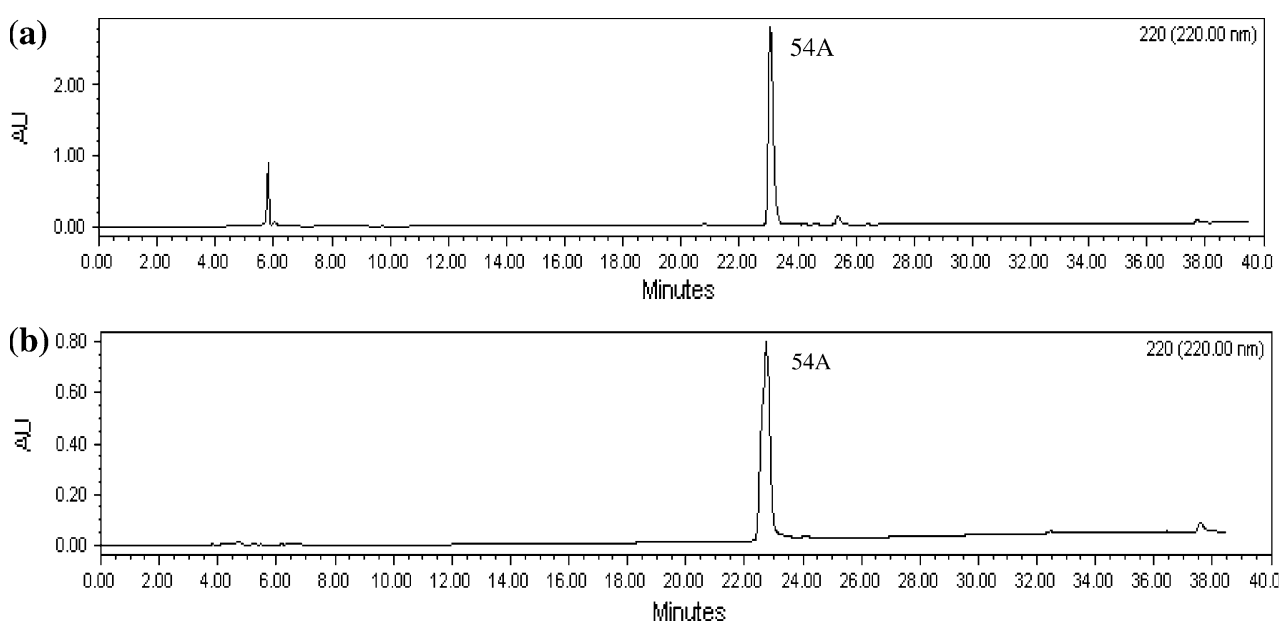

purification (Fig. 3). A quantity of $5.5 \mathrm{mg}$ of purified antibiotic was obtained from $250 \mathrm{~mL}$ of culture filtrate. The chromogenic reactions were negative with $\mathrm{FeCl}_{3}$, naphtoresorcinol- $\mathrm{H}_{2} \mathrm{SO}_{4}$, ninhydrine, formaldehyde- $\mathrm{H}_{2} \mathrm{SO}_{4}$ and Dragendorff reagents, suggesting the absence of phenol, osidic residues, free amine groups, polycyclic aromatics and alkaloids.

Spectroscopic analysis of antibiotics

The uv-visible spectrum of antibiotic 54A showed maxima at 213 and $273 \mathrm{~nm}$. The mass spectrum of the compound was obtained in positive and negative mode. The negative mode yielded a pseudo-molecular ion $[\mathrm{M}-\mathrm{H}]=321$. Thus the molecular weight of antibiotic 54A is $\mathrm{M}=322$.

${ }^{1} \mathrm{H}$ and ${ }^{13} \mathrm{C}$ NMR spectroscopy were used for the characterization of compound $54 \mathrm{~A}$. All the ${ }^{1} \mathrm{H}$ and ${ }^{13} \mathrm{C}$ signals were assigned on the basis of chemical shifts, spin-spin coupling constants, splitting patterns and signal intensities, and by using ${ }^{1} \mathrm{H}-{ }^{1} \mathrm{H}$ COSY $45,{ }^{1} \mathrm{H}_{-}{ }^{13} \mathrm{C}$ HSQC and ${ }^{1} \mathrm{H}^{-1}{ }^{13} \mathrm{C}$ HMBC experiments. The ${ }^{1} \mathrm{H}$ and ${ }^{13} \mathrm{C}$ chemical shifts of compound 54A are given in Table 4 and Fig. 4.

The ${ }^{13} \mathrm{C}$ and HSQC spectra show 11 carbon signals. From the ${ }^{13} \mathrm{C}$ data, it was possible to discern one amide group $\left(\delta_{c} 165.2\right)$, five $\mathrm{sp}^{2}$-hybridized carbons ( $\delta_{c}$ from 150.2 to 122.8$)$ and four $\mathrm{sp}^{3}$-hybridized carbons bearing electronegative heteroatoms $\left(\delta_{c} 69.9-57.1\right)$. The ${ }^{1} \mathrm{H}$ NMR spectrum revealed AA' $X X$ ' system characteristic of dimeta substituted aromatic ring $\left(\delta_{c} 8.19\right.$ and $\left.7.66,4 \mathrm{H}, \mathrm{m}\right)$ and a hydroxymethyl group with diastereostopic hydrogens $\left(\delta_{c}\right.$ 3.63 and $3.83,2 \mathrm{H}$, dd, $\mathrm{J}=6.0 \mathrm{~Hz} ; 12.0 \mathrm{~Hz}$ ). The hydrogens of the hydroxyl and amide groups were not observed due to rapid exchange with MeOD. The 2D ${ }^{1} \mathrm{H}-{ }^{1} \mathrm{H}$ and ${ }^{1} \mathrm{H}_{-}{ }^{13} \mathrm{C}$ experiments, and especially the long range ${ }^{1} \mathrm{H}_{-}{ }^{13} \mathrm{C}$ couplings observed in the HMBC spectrum (Fig. 5), permitted the connectivity between all the groups of the molecule to be established.
Table $4{ }^{1} \mathrm{H}$ and ${ }^{13} \mathrm{C}$ NMR data assignments of 54A compound in $\mathrm{CD}_{3} \mathrm{OD}$ at $298 \mathrm{~K}$

\begin{tabular}{lll}
\hline $\begin{array}{l}{ }^{1} \mathrm{H} \text { and } \\
\text { number }\end{array}$ & $\begin{array}{l}{ }^{13} \mathrm{C} \text { chemical } \\
\text { shift ppm }\end{array}$ & $\begin{array}{l}{ }^{13} \mathrm{C} \text { chemical } \\
\text { shift ppm }\end{array}$ \\
1 & - & 147.2 \\
2,6 & 8.2 & 127.8 \\
3,5 & 7.7 & 127.0 \\
4 & - & 150.2 \\
7 & 5.2 & 69.9 \\
8 & 4.2 & 57.1 \\
9 & $3.6-3.8$ & 60.8 \\
10 & - & 165.2 \\
11 & 6.3 & 66.0 \\
\hline
\end{tabular}

See Fig. 4 for numbering of hydrogen and carbon atoms

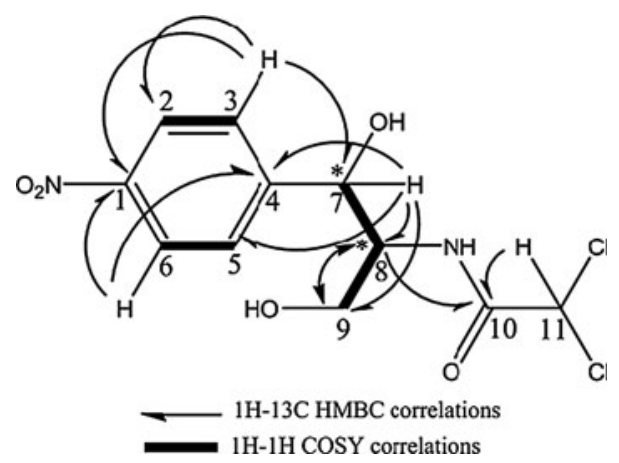

Fig. 4 Hydrogen, carbon numbering, COSY and HMBC correlations of $54 \mathrm{~A}$ compound. $*$ asymmetric carbon atoms

The structure of compound $54 \mathrm{~A}$ was determined by NMR and mass spectrometry to be 2,2-dichloro-N-(1,3dihydroxy-1-(4-nitrophenyl)propan-2-yl)acetamide. This structure corresponds to that of chloramphenicol.

It can be seen that there are two asymmetric carbon atoms on chloramphenicol, leading to four possible stereoisomers. In this study, we used the Karplus relationship 
<smiles>O=C(N[C@H](CO)[C@H](O)c1ccc([N+](=O)[O-])cc1)C(Cl)Cl</smiles>

Fig. 5 Structure of $D(-)$-threo chloramphenicol stereoisomer

in order to identify the stereoisomer 54A purified. The ${ }^{3} \mathrm{~J}$-coupling constants for (H7-H8), (H7-C9) and (H8-C4) were around $3-4 \mathrm{~Hz}$, which corresponds to a dihedral angle of $45-50^{\circ}$. Based on these results, there are 2 possible conformations: $(\mathrm{R}, \mathrm{R})$ or $\mathrm{D}(-)$-threo form, and $(\mathrm{S}, \mathrm{S})$ or $\mathrm{L}(+)$-threo form. Only the $\mathrm{D}(-)$-threo form (the naturally occurring isomer) of chloramphenicol has biological activity (Yunis 1988). This suggests that the antibiotic 54A is $\mathrm{D}(-)$-threo chloramphenicol (Fig. 5).

Chloramphenicol is an antibiotic belonging to the family of aromatic benzene. It is known to be produced by Streptomyces venezuelae and also $S$. omiyaensis and $S$. phaeochromogenes, but is also manufactured synthetically because of its relatively simple structure (Umezawa et al. 1949; Asselineau and Zalta 1973; Doull et al. 1983). It has never been reported in another microorganism. This antibiotic is active against Gram-positive and Gram-negative bacteria and against rickettsia, mycoplasma and chlamydia. It is bacteriostatic and inhibits peptide bond synthesis at the 50S ribosomal subunit by interfering with peptidyl transferase (Yunis 1988). The resistance to chloramphenicol of target bacteria used in this study might have allowed the selection of a chloramphenicol-producing strain.

Saccharothrix species have been reported to produce antibiotics belonging to aminoglycoside and benzoquinone (Takahashi et al. 1986), glycopeptide (Takeuchi et al. 1992), carboxylic nucleoside (Bush et al. 1993), dithiolopyrrolone (Lamari et al. 2002), heptadecaglycoside (Singh et al. 2000), anthracyclin (Zitouni et al. 2004b), macrolide (Murakami et al. 2009) and angucycline (Kalinovskaya et al. 2010) families. The fact that Saccharothrix produces chloramphenicol is itself quite original.

\section{References}

Aggoune-Khinache N, Bensersa D, Henniche FZ, Daoudi M, Abdouni MA, Chabani A, Tiouit D, Naim M (2008) Metallo-betalactamases producing Pseudomonas aeruginosa in Algeria. Med Mal Infect 39:413-414
Asselineau J, Zalta P (1973) Les antibiotiques: structure et exemples de mode d'action. Hermann, Paris

Becker B, Lechevalier MP, Gordon RE, Lechevalier HA (1964) Rapid differentiation between Nocardia and Streptomyces by paper chromatography of whole-cell hydrolysates. Appl Microbiol 12:421-423

Betina V (1973) Bioautography in paper and thin layer chromatography and its scope in the antibiotic field. J Chromatogr 78:41-51

Boudjella H, Zitouni A, Coppel C, Mathieu F, Monje M-C, Sabaou N, Lebrihi A (2010) Antibiotic R2, a new angucyclinone compound from Streptosporangium sp. Sg3. J Antibiot 63:709-711

Bush BD, Fitchett GV, Gates DA, Langely D (1993) Carbocyclic nucleosides from a species of Saccharothrix. Phytochemistry 32:737-739

Cashion P, Hodler-Franklin MA, McCully J, Franklin M (1977) A rapid method for base ratio determination of bacterial DNA. Anal Biochem 81:461-466

De Ley J, Cattoir H, Reynaerts A (1970) The quantitative measurement of DNA hybridization from renaturation rates. Eur J Biochem 12:133-142

Doull JL, Vining LC, Stuttard C (1983) A cryptic plasmid in the chloramphenicol-producing actinomycete, Streptomyces phaeochromogenes. FEMS Microbiol Lett 16:349-352

Felsenstein J (1985) Confidence limits on phylogenies: an approach using the bootstrap. Evolution 39:783-791

Genilloud O, Gonzalez I, Salazar O, Martin J, Tormo JR, Vicente F (2011) Current approaches to exploit actinomycetes as a source of novel natural products. J Ind Microbiol Biotechnol 38:375-789

Grund E, Kroppenstedt RM (1989) Transfer of five Nocardiopsis species to the genus Saccharothrix Labeda et al. 1984. Syst Appl Microbiol 10:267-274

Hayakawa M, Nonomura H (1987) Humic acid-vitamin agar, a new medium for the selective isolation of soil actinomycetes. J Ferm Technol 65:501-509

Horvath G, Brazhnikova MG, Konstantinova NV, Tolstykh IV, Potapova NP (1979) The structure of nocamycin, a new antitumor antibiotic. J Antibiot 32:555-558

Jukes TH, Cantor CR (1969) Evolution of protein molecules. In: Munro HN (ed) Mammalian protein metabolism, vol 3 . Academic Press, New York, pp 21-132

Kalinovskaya NI, Kalinovsky AI, Romanenko LA, Dmitrenok PS, Kuznetsova TA (2010) New angucyclines and antimicrobial diketopiperazines from the marine mollusk-derived actinomycete Saccharothrix espanaensis An 113. Nat Prod Commun 5:597-602

Katsumi S, Kazshi T, Hiroshi O (2005) Pathogen occurrence and antimicrobial susceptibility of urinary tract infection cases during a 20-year period (1983-2002) at a single institution in Japan. Jpn J Infect Dis 58:303-308

Kelly KL, Judd DB (1976) Color. Universal Language and Dictionary of Names-National bureau of standards, special publication 440 . US Department of Commerce, Washington

Kim B-Y, Brown R, Labeda DP, Goodfellow M (2011) Reclassification of 'Dactylosporangium variesporum' as Saccharothrix variisporea corrig. (ex Tomita et al. 1977) sp. nov., nom. rev. Int J Syst Evol Microbiol 61:310-314

Kroppenstedt RM, Evtushenko LI (2006) The family Nocardiopsaceae. In: Dworkin $\mathrm{M}$ et al (eds) The prokaryotes. A handbook on biology of bacteria, 3rd edn. Springer, New York, pp 754-795

Kumar S, Tamura K, Nei M (2004) MEGA3: integrated software for molecular evolutionary genetic analysis and sequence alignment. Briefings Bioinfo 5:150-163

Kumarasamy KK, Toleman MA, Walsh TR et al (2010) Emergence of a new antibiotic resistance mechanism in India, Pakistan, and 
the UK: a molecular, biological, and epidemiological study. The Lancet Infect Dis 10:597-602

Labeda DP (2002) The family Actinosynnemataceae. In: Dworkin M et al (eds) The prokaryotes, 3rd edn. Springer, New York, pp 654-668

Labeda DP, Testa RT, Lechevalier MP, Lechevalier HA (1984) Saccharothrix, a new genus of the Actinomycetales related to Nocardiopsis. Int J Syst Bacteriol 34:426-431

Lamari L, Zitouni A, Boudjella H, Badji B, Sabaou N, Lebrihi A, Lefebvre G, Seguin E, Tillequin F (2002) New dithiolopyrrolone antibiotics from Saccharothrix sp. SA 233. I. Taxonomy, fermentation, isolation and biological activities. J Antibiot 55:696-701

Lechevalier MP, Lechevalier HA (1970) Chemical composition as a criterion in the classification of aerobic actinomycetes. Int J Syst Bacteriol 20:435-443

Lechevalier MP, de Bievre C, Lechevalier HA (1977) Chemotaxonomy of aerobic actinomycetes: phospholipid composition. Biochem Syst Ecol 5:249-260

Liu D, Coloe S, Baird R, Pedersen J (2000) Rapid mini-preparation of fungal DNA for PCR. J Clinical Microbiol 38:471

Locci R (1989) Streptomycetes and related genera. In: Williams ST, Sharpe ME, Holt JG (eds) Bergey's manual of systematic bacteriology, vol 4. Williams and Wilkins, Baltimore, pp 2451-2492

Marchal N, Bourdon JL, Richard CL (1987) Les milieux de culture pour l'isolement et l'identification biochimique des bactéries. Doin Press, Paris

Marmur J (1961) A procedure for the isolation of deoxyribonucleic acid from microorganisms. J Mol Biol 3:208-218

Merrouche R, Bouras N, Coppel Y, Mathieu F, Monje M-C, Sabaou N, Lebrihi A (2010) Dithiolopyrrolone antibiotic formation induced by adding valeric acid to the culture broth of Saccharothrix algeriensis. J Nat Prod 73:1164-1166

Messai Y, Iabadene H, Benhassine T, Alouache S, Tazir M, Gautier V, Arlet G, Bakour R (2008) Prevalence and characterization of extended-spectrum $\beta$-lactamases in Klebsiella pneumoniae in Algiers hospitals (Algeria). Pathol Biol 56:319-325

Minnikin DE, Patel PV, Alshamaony L, Goodfellow M (1977) Polar lipid composition in the classification of Nocardia and related bacteria. Int J Syst Bacteriol 27:104-117

Murakami R, Shinozaki J, Kajiura T, Kozone I, Takagi M, Shin-Ya K, Seto H, Hayakawa Y (2009) Ammocidins B, C and D, new cytotoxic 20-membered macrolides from Saccharothrix sp. AJ9571. J Antibiot 62:123-127

Sabaou N, Boudjella H, Bennadji A, Mostefaoui A, Zitouni A, Lamari L, Bennadji H, Lefebvre G, Germain P (1998) Les sols des oasis du Sahara algérien, source d'actinomycètes rares producteurs d'antibiotiques. Sécheresse 9:147-153

Saitou N, Nei M (1987) The neighbor-joining method: a new method for reconstructing phylogenetic trees. Mol Biol Evol 4:406-425

Sekhsokh Y, Chadli M, El Hamzaoui SA (2008) Fréquence et sensibilité aux antibiotiques des bactéries isolées dans les urines. Med Mal Infect 38:324-327
Shirling EB, Gottlieb D (1966) Methods for characterization of Streptomyces species. Int J Syst Bacteriol 13:313-340

Singh MP, Petersen PJ, Weiss WJ, Kong F, Greenstein M (2000) Saccharomicins, novel heptadecaglycoside antibiotics produced by Saccharothrix espanaensis: antibacterial and mechanistic activities. Antimicrob Agents Chemother 44:2154-2159

Solanki R, Khanna M, Lal R (2008) Bioactive compounds from marine actinomycetes. Indian $\mathrm{J}$ Microbiol 48:410-431

Takahashi A, Hotta K, Saito N, Morioka M, Okami Y, Umezawa H (1986) Production of novel antibiotic, dopsisamine by a new subspecies of Nocardiopsis mutabilis with multiple antibiotic resistance. J Antibiot 39:175-183

Takeuchi M, Takahashi S, Enokita R, Sakaida Y, Haruyama H, Nakamura T, Katayama T, Inukai M (1992) Galacardines A and B, new glycopeptide antibiotics. J Antibiot 45:297-305

Thompson JD, Higgins DG, Gibson TJ (1994) CLUSTAL W: improving the sensitivity of progressive multiple sequence alignment through sequence weighing, position-specific gap penalties and weight matrix choice. Nucleic Acids Res 22:4673-4680

Touati A, Benallaoua S, Forte D, Madoux J, Brasme L, de Champs C (2006) First report of CTX-M-15 and CTX-M-3 beta-lactamases among clinical isolates of Enterobacteriaceae in Bejaia, Algeria. Int J Antimicrob Agents 27:397-402

Umezawa H, Tazaki T, Okami Y, Fukuyama S (1949) On the new source of chloromycetin, Streptomyces omiyaensis. J Antibiot 3:292-296

Valan Arasu M, Duraipandiyan V, Agastian P, Ignacimuthu S (2008) Antimicrobial activity of Streptomyces spp. ERI-26 recovered from Western Ghats of Tamil Nadu. J Mycol Med 18:147-153

Vertesy L, Barbone FP, Cashmen E, Decker H, Ehrlich K, Jordan B, Knauf M, Schummer D, Segeth MP, Wink J, Seibert G (2001) Pluraflavins, potent antitumor antibiotics from Saccharothrix sp. DSM 12931. J Antibiot 54:718-729

Wayne LG, Brenner DJ, Colwell RR et al (1987) Report of the ad hoc committee on reconciliation of approaches to bacterial systematics. Int J Syst Bacteriol 37:463-464

Yunis AA (1988) Chloramphenicol: relation of structure to activity and toxicity. Ann Rev Pharmacol Toxicol 28:83-100

Zitouni A, Lamari L, Boudjella H, Badji B, Sabaou N, Gaouar A, Mathieu F, Lebrihi A, Labeda DP (2004a) Saccharothrix algeriensis sp. nov., isolated from Saharan soil. Int J Syst Evol Microbiol 54:1377-1381

Zitouni A, Mathieu F, Coppel Y, Pont F, Sabaou N, Lebrihi A (2004b) Mutactimycin PR, a new anthracycline antibiotic from Saccharothrix sp. SA 103. II. Physico-chemical properties and structure elucidation. J Antibiot 57:373-378

Zitouni A, Boudjella H, Lamari L, Badji B, Mathieu F, Lebrihi A, Sabaou N (2005) Nocardiopsis and Saccharothrix genera in Saharan soils in Algeria: isolation, biological activities and partial characterization of antibiotics. Res Microbiol 156:984-993 